\title{
The occurrence of the endemic tiger beetle Cicindela (Ifasina) waterhousei in Bopath Ella, Ratnapura
}

\author{
Chandima Dangalle ${ }^{1 *}$, Nirmalie Pallewatta ${ }^{1}$ and Alfried Vogler ${ }^{2}$ \\ ${ }^{I}$ Department of Zoology, Faculty of Science, University of Colombo, Colombo 03. \\ ${ }^{2}$ Department of Entomology, The Natural History Museum, London SW7 5BD, United Kingdom.
}

Revised: 04 January 2011 ; Accepted: 21 January 2011

\begin{abstract}
The occurrence of the endemic tiger beetle Cicindela (Ifasina) waterhousei from Bopath Ella, Ratnapura is recorded for the first time. The study reveals a population of 276 beetles from the sandy bank habitat of Bopath Ella. A site description is given stating the abiotic environmental factors of climate and soil. Morphology of the species is described using diagnostic features of the genus, and in comparison with reference specimens at the Department of National Museums, Colombo and the type specimen at the British Natural History Museum, London. According to the findings of the study, at present, the species is recorded only from Bopath Ella and is absent from its previously recorded locations at Labugama, Kitulgala, Karawanella and Avissawella. The habitat conditions in Bopath Ella with shady, riverine areas, temperatures ranging from 32 to $35^{\circ} \mathrm{C}$ and yellow brown sandy moist soil are considered as suitable for the occurrence of $C$. waterhousei. The presence of other tiger beetle species, Cicindela (Ifasina) willeyi and Cicindela (Ifasina) labioaenea, in the previously recorded locations of Cicindela waterhousei, that may compete for food, thermal resources, oviposition sites and larval resources, is likely to have caused $C$. waterhousei to become locally displaced from its previous locations.
\end{abstract}

Keywords: Cicindela (Ifasina) waterhousei, conservation, displacement, environmental factors, habitat suitability.

\section{INTRODUCTION}

Tiger beetles (Coleoptera: Cicindelidae) are a group of predatory insects that have a worldwide distribution (Pearson, 1988). A total of 2,559 species have been described globally from a range of habitats such as river edges, open beaches, sand dunes, forests and grasslands (Pearson \& Cassola, 2005). Most species are habitat specialists being restricted to one or two habitat types due to the requirements of both adults and larvae (Barraclough et al., 1999). The majority of tiger beetle species are found in the Oriental region of the world in countries such as Malaysia, Indonesia, Japan and China (Pearson, 1988). Fifty-six species have been recorded from Sri Lanka of which thirty-five species are said to be endemic to the island (Cassola \& Pearson, 2000).

Cicindela (Ifasina) waterhousei Horn is endemic to Sri Lanka and has been recorded along watercourses within dark, moist forests of Labugama (Colombo District, Western Province), Avissawella (Colombo District, Western Province), Kitulgala (Kegalle District, Sabaragamuwa Province) and Karawanella (Kegalle District, Sabaragamuwa Province) (Naviaux, 1984; Acciavatti \& Pearson, 1989). The subgenus Ifasina is the largest with seven species in Sri Lanka, of which five are endemic. The paper reports the occurrence of one of the species; Cicindela waterhousei from a site previously not recorded, and its absence from previously recorded locations including Labugama, Avissawella, Kitulgala and Karawanella.

\section{METHODS AND MATERIALS}

A country-wide study in Sri Lanka was carried out in Bopath Ella in 2003-2007 with regard to the habitat preferences and occurrence of tiger beetles. The study also included localities where the beetles have been recorded previously. Bopath Ella (6 $\left.6^{\circ} 48^{\prime} 06 \mathrm{~N}, 80^{\circ} 22^{\prime} 04 \mathrm{E}\right)$ is a well known waterfall located in the Ratnapura District in the Sabaragamuwa Province of Southwestern Sri Lanka (Figure 1).

Six visits were made to four sections of the study site for surveying adult tiger beetles. These sections are: Section A, which falls to a depth of $30 \mathrm{~m}$; Section B, 
which is about $150 \mathrm{~m}$ from section A; Section C, left river bank along the Kuru Ganga, which is a tributary of the Kalu Ganga and Section D, which is a wide right river bank site in the Kuru Ganga. Section A, B, C and D were thoroughly observed and searched for the presence of tiger beetles and the sections where beetles were found were subjected to detailed studies. Stretches of land of $100-150 \mathrm{~m}$ were selected in five sandy banks of the sections from where beetles were examined for 3 hours, between 11 a.m. to 2 p.m. on each day of the $6 \mathrm{~d}$ visits. Specific habitats and their immediate surroundings were searched. Tiger beetles encountered were rapidly counted using a tally counter and a sample was collected using a standard insect net.

Taxonomic keys of the Cicindela of the Indian subcontinent by Acciavatti \& Pearson (1989) and descriptions of Horn (1904) and Fowler (1912) were used to identify the specimens, and confirmed by comparisons with reference specimens at the Department of National Museums, Colombo and type specimen at the British Natural History Museum, London.
Previous localities from where Cicindela waterhousei has been recorded, Labugama (sites near the Labugama reservoir, river banks of Wak Oya and Heen Ela, Waga), Avissawella (river banks of Asvathu Oya and Ranwala Ferry, Avissawella), Kitulgala (river banks of the Kelani River near Kitulgala) and Karawanella (river banks of the Seethawaka River and the Maha Oya, Dehiowita) were also surveyed and subjected to detailed studies. The tiger beetle species occurring in these localities were recorded. The habitat variables of climate and soil, required by tiger beetles (Eusebi et al., 1989; Morgan et al., 2000; Brust et al., 2005) were measured and recorded for all localities investigated using standard methods.

The temperature, solar radiation, relative humidity and wind speed of the habitats were recorded using a portable integrated weather station (Health EnviroMonitor, USA).

Soil variables of the habitat such as the soil group based on the Soil Map of Sri Lanka; soil type based on the "soil textural triangle"; soil colour based on the

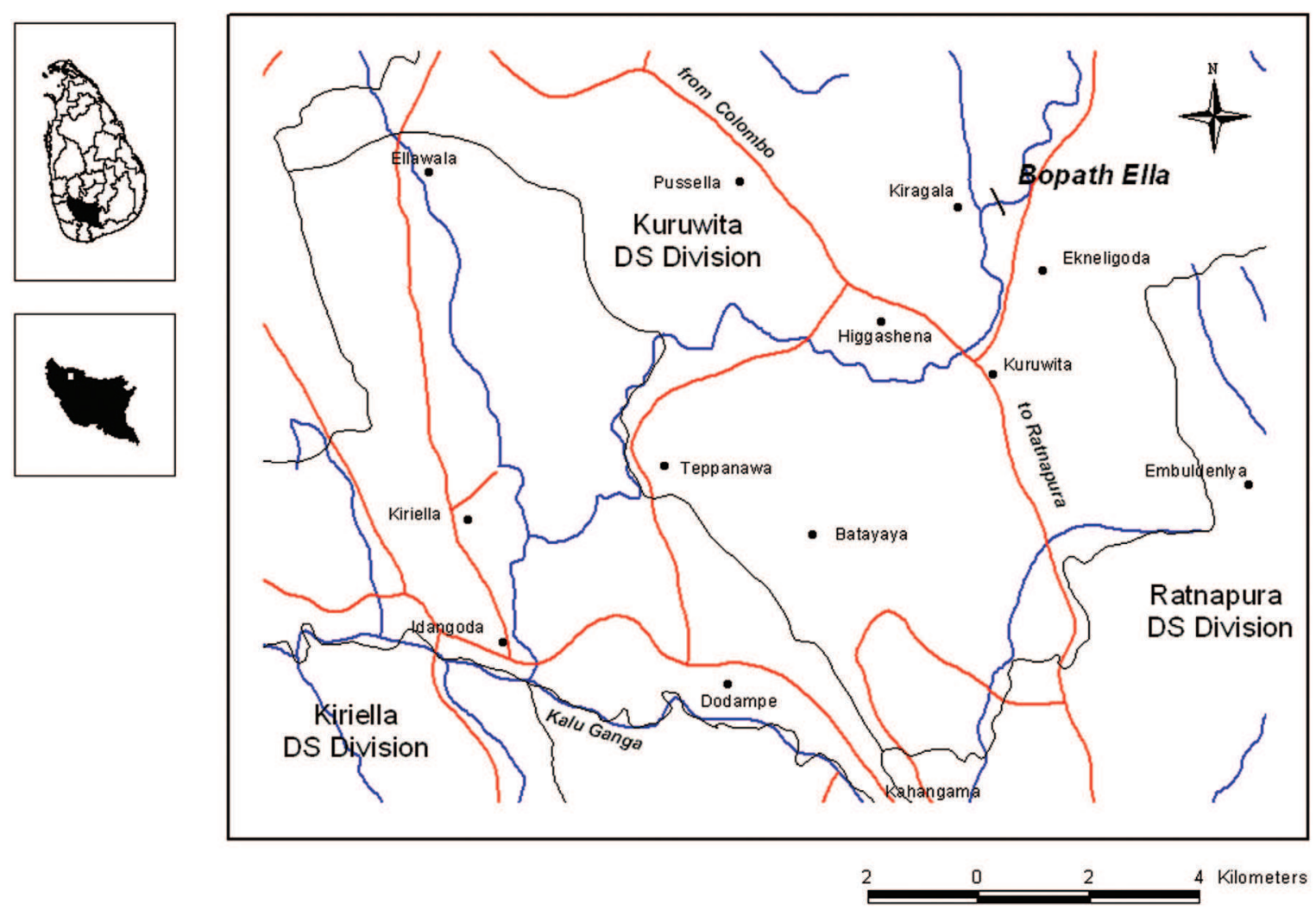

Figure 1: Location of Bopath Ella, Ratnapura District 
Munsell soil colour chart; soil temperature using a soil thermometer; soil $\mathrm{pH}$ using a portable soil $\mathrm{pH}$ meter; soil moisture based on the method used by Ganeshaiah \& Belavadi (1986) and soil salinity using a hand-held salinity meter were also measured.
The climate and soil parameter values of the localities of Cicindela waterhousei were compared statistically using two-way ANOVA (SPSS 13.0 package).Morphological features such as body length; mandible length; colour of dorsal and ventral body surfaces, elytral maculae,

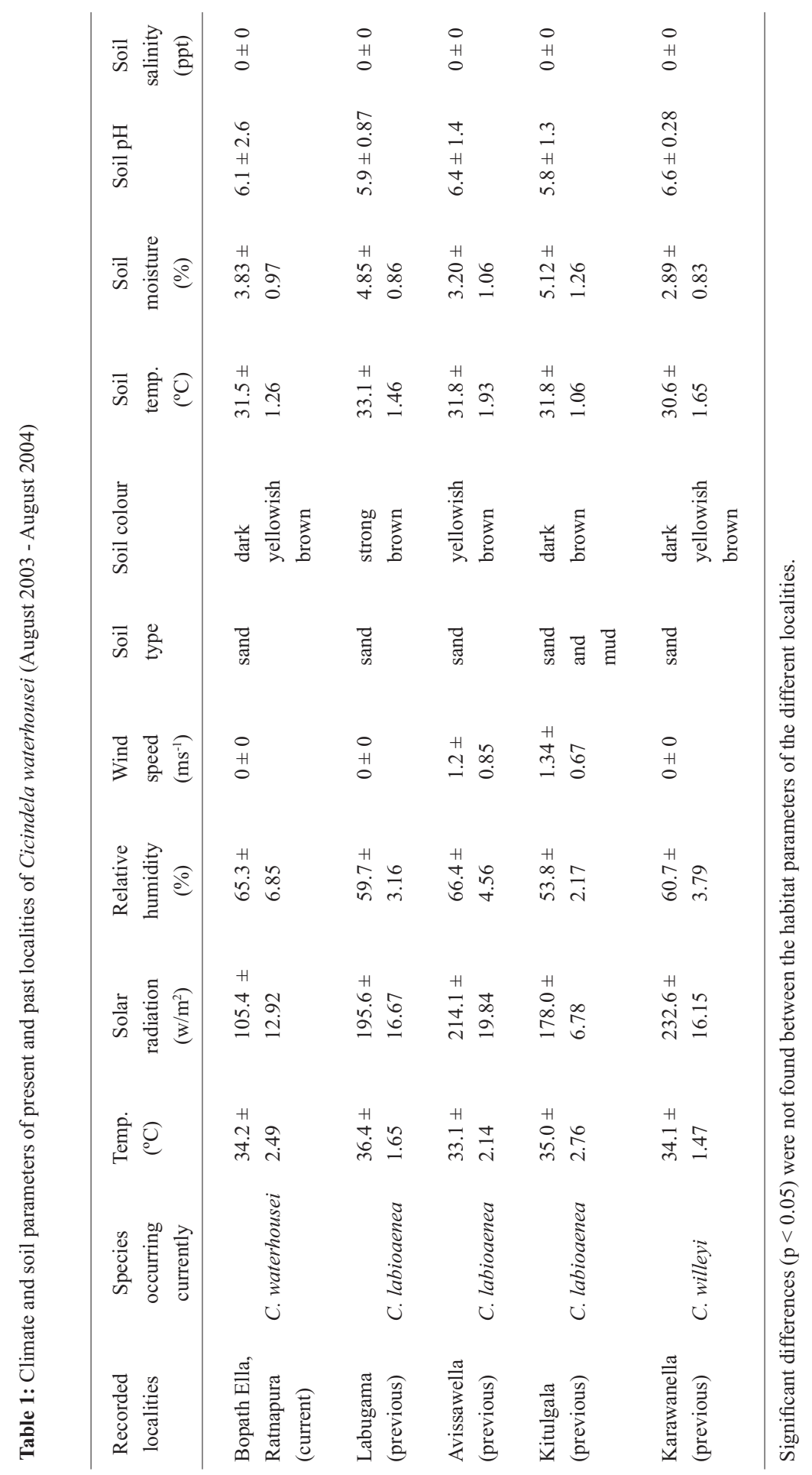




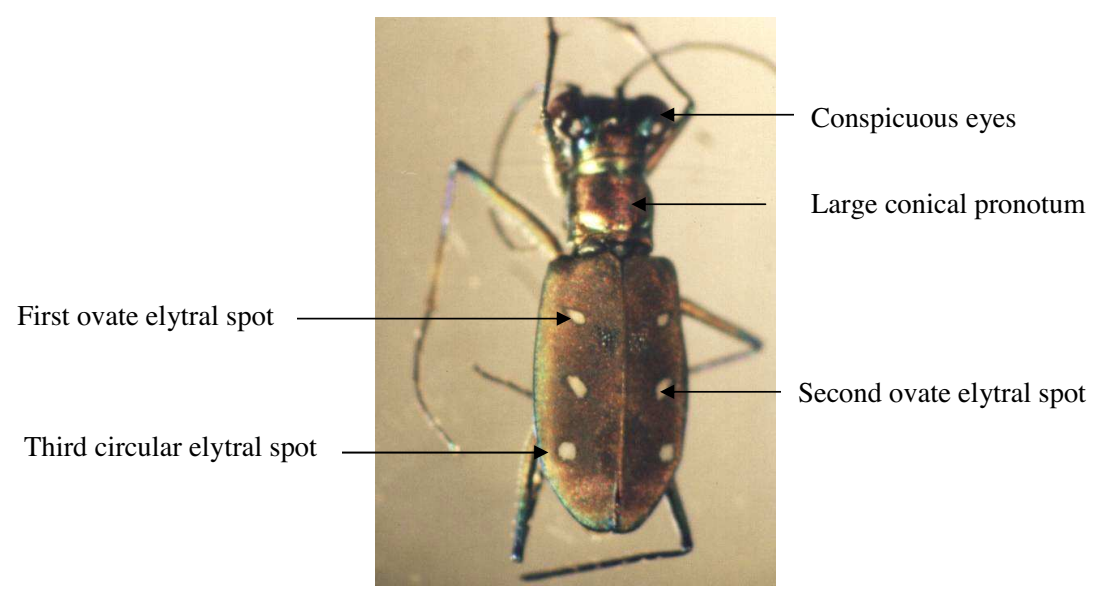

Figure 2: Cicindela (Ifasina) waterhousei adult $(\times 10)$

mandibles, labrum and legs; pattern of elytral markings; the shape of the labrum and the number of labral setae; distribution of setae and pits on body were recorded for identification and confirmation of the species.

\section{RESULTS}

Preliminary reconnaissance visits to the waterfall area revealed that tiger beetles are absent in sections A, B and $\mathrm{C}$ but present in exposed sandy banks in the shallow parts of section D. Here, 276 tiger beetles of the species C. waterhousei were encountered on a sandy bank, $600 \mathrm{~m}^{2}$ in extent and at $16.46 \mathrm{~m}$ elevation. This sandy bank was situated away from the waterfall adjacent to a part of the Kuru Ganga that flows slowly $\left(0.5 \mathrm{~ms}^{-1}\right)$. The vegetation in the immediate surroundings consisted of large trees such as Arecanut (Areca catechu) and Jak (Artocarpus heterophyllus) and shrubs such as Pandanus, bamboo, long grasses and ferns that provided shade to the habitat. The climatic and soil conditions of the habitat are given in Table 1.

The identities of the tiger beetles collected at Bopath Ella as C. waterhousei was confirmed by the presence of a short testaceous labrum, three spots in a line medially on each elytron and a pronotum with a dorsal bulge divided in two by a medial line (Acciavatti \& Pearson, 1989). In addition to these diagnostic features, $C$. waterhouse possessed the following characteristics: small slender body $8.76 \pm 0.23 \mathrm{~mm}$ in length and $26.4 \pm 2.71 \mathrm{mg}$ in weight $(\mathrm{n}=15)$; dorsal surface of head, pronotum and elytra metallic brown while the ventral surface is iridescent bluish-green; three yellowish-white spots on each elytron arranged medially in a single row; first and middle elytral spots ovate in shape and last elytral spot circular in shape (some specimens had a humeral elytral dot that was in line with the three spots); mandibles brown in colour, left mandible $1.72 \pm 0.38 \mathrm{~mm}$ in length $(\mathrm{n}=15)$; labrum brown in colour and conical in shape with 10 labral setae; white setae on ventral surface of body and legs; shallow blue-green pits on the basal half of the dorsal surface of elytra; legs blue-green (Figure 2).

C. waterhousei was not found in previously recorded localities in Labugama, Avissawella, Kitulgala and Karawanella. Two other species of tiger beetles were encountered in these locations. Cicindela (Ifasina) labioaenea was found at Heen Ela, Waga in Labugama; Asvathu Oya, Avissawella; Seethawaka River bank near Karawanella and Kelani River banks near Kitulgala. Cicindela (Ifasina) willeyi was found at Maha Oya, Dehiowita in Karawanella. The habitat variables of the climate and soil of these localities were not significantly different from each other or from the habitats at Bopath Ella $(\mathrm{p}<0.05)$ (Table 1).

\section{DISCUSSION}

Cicindela waterhousei is an endemic tiger beetle species of Sri Lanka that was first recorded from the island as far back as 1904 (Horn, 1904), then in 1912 (Fowler, 1912) and much later in 1984 (Naviaux, 1984) from moist forests in Labugama, Kitulgala, Karawanella and Avissawella all of which are in the wet southwestern quarter of the island. The localities where collections of this species were made had been either riverine or moist rocky surfaces or soil (Acciavatti \& Pearson, 1989). It has not been recorded from drier, coastal or open habitats with sparse vegetation, grasslands or any other type of habitats. Therefore, the species could be considered as a habitat specialist. However, despite its endemicity and specific nature of habitat, habitat variables, morphometric 
features and sizes of populations have not been described previously. According to the present findings the species does not occur in any of the previously recorded locations and is recorded only from a new locality at Bopath Ella, Ratnapura on the sandy banks of the Kuru Ganga.

Tiger beetles are known to prefer riverine habitats because of close proximity to prey and high humidity, safety from predators and reasonably low human disturbance (Bhargav \& Uniyal, 2008). Shade in the habitat is used as an oviposition cue by many cicindelid species and burrows for larvae are constructed near bases of plants (Brust et al., 2005). Further, their activity and density are known to be largely influenced by daily temperature patterns. Ground temperatures ranging from $32-35{ }^{\circ} \mathrm{C}$ is known to be suitable for the activity and viability of tiger beetle populations, and temperatures $34-35^{\circ} \mathrm{C}$ was recorded at the highest number of matings in Cicindela (Cephalota) circumdata leonschaeferi Cassola (Eusebi et al., 1989).

Tiger beetles are known to prefer sandy soils with sparse vegetation, where periodic disturbance by wind and water removes encroaching vegetation. The sandy soils maybe preferred to clay soils as excavation of oviposition holes are much easier in sandy loose soil where females dig multiple holes prior to laying eggs (Hoback et al., 2000). Moist soils are required for oviposition and survival of larvae of most cicindelid species. Dessication of the substrate presents problems for emerging larvae. Colour patterns of adult tiger beetle species closely resemble the texture and hue of the soil substrate on which they are found. Matching of the body colour with that of the soil plays an important role in evading predators and not being recognized (Morgan et al., 2000).

The habitat at Bopath Ella may be preferred by C. waterhousei as it is shady and located near a slow flowing stream. The diurnal temperatures and solar radiations recorded are likely to provide favourable conditions for the temperature-dependent predation of these ectothermic beetles (Eusebi et al., 1989). The metallic brown colour of the species also blends with the dark yellowish brown wet sand substrates on which they are found and provides camouflage against predators. The habitat variables at Bopath Ella are similar to the environmental parameters stated for tiger beetles in the literature (Eusebi et al., 1989; Hoback et al., 2000; Morgan et al., 2000; Brust et al., 2005; Bhargav \& Uniyal, 2008).

The habitat variables of the localities where tiger beetles have been recorded previously, at Labugama,
Avissawella, Kitulgala and Karawanella, are also suitable for their occurrence. The climatic and soil variables of these locations are not significantly different from those at Bopath Ella $(\mathrm{p}<0.05)$ (Table 1). As reported, large populations of Cicindela (Ifasina) labioaenea were found on the Kelani River banks near Kitulgala; Asvathu Oya, Avissawella; Heen Ela, Labugama and Seethawaka River, Karawanella. Cicindela (Ifasina) willeyi was found on the stream banks of Maha Oya located between Dehiowita and Karawanella. Cicindela labioaenea is a widely distributed tiger beetle species in Sri Lanka and was found on the river banks of eleven (11) localities during the present study. Therefore it is likely that these species may have displaced $C$. waterhousei by competing for resources. Tiger beetles of different species have known to compete for food resources, thermal resources, oviposition sites and larval resources when they co-occur in the same location (Romey \& Knisley, 2002; Satoh et al., 2006). It is likely that $C$. waterhouse $i$ was eliminated from its original sites in Labugama, Avissawella, Kitulgala and Karawanella due to interspecific competition, and not due to unsuitability of the localities. Bopath Ella which is an isolated location with suitable climatic and soil variables for tiger beetles may have provided suitable conditions for $C$. waterhousei as is seen by its large population.

Since $C$. waterhouse $i$ is an endemic species probably limited in distribution and subject to local extinction, it is important that the location at Bopath Ella be identified and protected. The most important conservation priority of a country should be the protection of areas where large populations of endemic species occur. This study provides evidence of Bopath Ella as a location, harbouring at present the only known population of an endemic species of tiger beetle, $C$. waterhousei. Conservation of this site is essential for the survival of this species.

\section{Acknowledgement}

The National Science Foundation (NSF) of Sri Lanka (Research Grant No. RG/2003/ZOO/01) is acknowledged for funding the study. Authors are indebted to the Department of Zoology, University of Colombo; Natural History Museum, London, UK and Department of Wildlife Conservation, Sri Lanka. Professor Y.N.A. Jayatunga, University of Colombo, is acknowledged for providing constructive comments on the manuscript. We are grateful to Prof. Nimal Dangalle, Department of Geography, University of Kelaniya for his assistance in the preparation of maps.

\section{REFERENCES}

1. Pearson D.L. (1988). Biology of tiger beetles. Annual 
Review of Entomology 33: 123-147.

2. Pearson D.L. \& Cassola F. (2005). A quantitative analysis of species descriptions of tiger beetles (Coleoptera: Cicindelidae), from 1758 to 2004, and notes about related developments in biodiversity studies. The Coleopterists Bulletin 59(2): 184-193.

3. Barraclough T.G., Hogan J.E. \& Vogler A.P. (1999). Testing whether ecological factors promote cladogenesis in a group of tiger beetles (Coleoptera: Cicindelidae). Proceedings of the Royal Society of London 266(423):1061-1067.

4. Cassola F. \& Pearson D.L. (2000). Global patterns of tiger beetle species richness (Coleoptera: Cicindelidae): their use in conservation planning. Biological Conservation 95:197-208

5. Naviaux R. (1984). Coleoptera, Cicindelidae. Les Cicindelés de Sri Lanka. Revue Scientifique $D u$ Bourbonnais: 57-80.

6. Acciavatti R.E. \& Pearson D.L. (1989). The tiger beetle genus Cicindela (Coleoptera, Insecta) from the Indian subcontinent. Annals of Carnegie Museum, 58(4): 77355.

7. Horn W. (1904). The Cicindelidae of Ceylon. Spolia Zeylanica 2(5): 30-45.

8. Fowler W.W. (1912). Coleoptera: General Introduction and Cicindelidae and Paussidae, Fauna of British India including Ceylon and Burma, pp. 529. Today and Tomorrow's Printers and Publishers, New Delhi, India.

9. Brust M., Hoback W.W. \& Knisley C.B. (2005). Biology, habitat preference, and larval description of Cicindela curtisans Leconte (Coleoptera: Carabidae: Cicindelinae).
The Coleopterists Bulletin 59(3): 379-390.

10. Eusebi M.P., Favilli L. \& Lovari S. (1989). Some abiotic factors affecting the activity and habitat choice of the tiger beetle Cephalota circumdata leonschaeferi (Cassola) (Coleoptera, Cicindelidae). Italian Journal of Zoology 56(2): 143-150.

11. Morgan M., Knisley C.B. \& Vogler A.P. (2000). New taxonomic status of the endangered tiger beetle Cicindela limbata albissima (Coleoptera: Cicindelidae): evidence from mtDNA. Annals of the Entomological Society of America 93(5): 1108-1115.

12. Ganeshaiah K.N. \& Belavadi V.V. (1986). Habitat segregation in four species of adult tiger beetles (Coleoptera: Cicindelidae). Ecological Entomology 11: 147-154.

13. Bhargav V.K. \& Uniyal V.P. (2008). Communal roosting of tiger beetles (Cicindelidae: Coleoptera) in the Shivalik Hills, Himachal Pradesh, India. Cicindela 40 (1-2): 1-12.

14. Hoback W. W., Golick D.A., Svatos T.M., Spomer S.M. \& Highley L.G. (2000). Salinity and shade preferences result in ovipositional differences between sympatric tiger beetle species. Ecological Entomology 25: 180-187.

15. Satoh A., Uéda T., Ichion E. \& Hori M. (2006). Distribution and habitat of three species of riparian tiger beetle in the Tedori River System of Japan. Environmental Entomology 35(2): 320-325.

16. Romey W.L. \& Knisley C.B. (2002). Microhabitat segregation of two Utah sand dune tiger beetles (Coleoptera: Cicindelidae). The Southwestern Naturalist 47(2): 169-174. 